Article

\title{
How Do Chinese Media Frame Arab Uprisings: A Content Analysis
}

\author{
Shiming Hu, Weipeng Hou and Jinghong Xu* \\ School of Journalism and communication, Beijing Normal University, China; E-Mails: 2737052943@qq.com (S.H.), \\ houweipengbnu@163.com (W.H.), 123abctg@163.com (J.X.) \\ * Corresponding author
}

Submitted: 30 April 2021 | Accepted: 2 November 2021 | Published: 17 December 2021

\begin{abstract}
Employing content analysis, this study compares the coverage of the Arab uprisings by the People's Daily (the official newspaper of the Communist Party of China) and Caixin Net (a typical commercial media) with statements from the Chinese Foreign Ministry in the last decade. It shows that the overall attention given to Arab uprisings in the People's Daily and Caixin Net declined during the period, but there were shifts in the framing of the conflicts, presentation of issues, and positions. The article demonstrates and analyses how the approach and outline of the conflicts in the People's Daily changed from disaster to criticism, and then to comparison-its position towards the events generally negative-and how Caixin Net moved from a disaster to a contextual framing of the events, its position tending to be neutral.
\end{abstract}

\section{Keywords}

Arab uprisings; Chinese media; content analysis; news framing

\section{Issue}

This article is part of the issue "Ten Years after the Arab Uprisings: Beyond Media and Liberation," edited by Hanan Badr (Gulf University for Science and Technology, Kuwait) and Lena-Maria Möller (Max Planck Institute for Comparative and International Private Law, Germany).

(C) 2021 by the authors; licensee Cogitatio (Lisbon, Portugal). This article is licensed under a Creative Commons Attribution 4.0 International License (CC BY).

\section{Introduction}

As Halbwachs (2020) said:

Memory is not to preserve the past, but to reconstruct the past with the help of material relics, rituals, scriptures, and traditions left by the past, and with the help of recent psychological and social materials, that is to say, the present.

Ten years passed since the Arab uprisings broke out, making it possible to look at this critical event objectively and rationally. Baum and Potter (2008, p. 49) said that "the media play a vital role in collecting, constructing, and disseminating information" and, as "the main link between leaders and the public, [they play] the core role in the foreign policy market." Cohen (2015, p. 13) said that "the [media] may not be able to tell readers what to think successfully, but it is surprisingly successful in telling readers what to think"; especially when readers don't have foreign contacts or do not understand important external context, they are more significantly influenced by the media (Kelly \& Smith, 2013). Research shows that the media played a vital role in the Arab uprisings of 2011 and subsequent social movements (Cottle, 2011), being held responsible for escalating unrest and for giving different explanations of the uprisings (Karyotakis et al., 2017).

According to Entman (1993, p. 52), "framing essentially involves selection and salience." Several studies have attempted to examine differences in how China and the US frame international issues (Akhavan-Majid \& Ramaprasad, 1998; Wu, 2006; Yin, 2007). Although some studies have examined differences between Chinese and Western media coverage of the Arab uprisings over some time (Du, 2016; Ha \& Shin, 2019; Karyotakis et al., 2017; Tzogopoulos, 2014), there is a lack of rigorous and in-depth analysis of China's views on Arab uprisings. In this article, we analyse how the People's Daily (the official newspaper of the Communist Party of China) and Caixin Net (a typical commercial media) covered 
the Arab uprisings. Since the political and social environment of a country inevitably influences its media, we propose Chinese official foreign policy tendencies as essential background, which expands the analysis beyond the Global North and reconstructs the disruptions while challenging normative models of media systems (Rodny-Gumede, 2020).

This study is of merit for several reasons. First, ten years have passed since the Arab uprisings in 2011 and the world has witnessed a great change, so it is time to reconsider the event. This is particularly true given that there has been an over-emphasis on the role of the state, ruling elites, and traditional political and civil society actors, which-it is assumed-operate to the detriment of societal forms of unstructured mobilisation such as non-traditional, leaderless, and horizontal social and political actors (Aarts \& Cavatorta, 2013). This research focuses on how People's Daily and Caixin Net had organised the coverage on the Arab uprisings during the past ten years. Results demonstrate that the framing of People's Daily changed from disaster to criticism and then to comparison, and that its position towards the events was generally negative. The framing of Caixin Net, on the other hand, changed from disaster to contextual framing, and its position tended to be neutral.

Second, this study also provides another perspective from which to view the uprisings. A study that conducted a keyword search of "Arab uprising" in Arabic, English, and French (excluding blogs, newspapers, and books), showed that the majority of articles on the Arab uprisings were produced outside the Arab world, with most of them being written in English (AIMaghlouth et al., 2015). Our research coming from China offers a diverse perspective and frame from the Global South.

Third, scholars have found that media framing cannot be detached from socially and politically dominant ideologies and rather tends to reflect the prevailing values of its society (Tuchman, 1978). This study explores several factors that may influence the framing of the Arab uprisings in the context of social media: ideology, geopolitics, and the particular media environment. Therefore, our research also contributes to a continuous observation of the changes in "framing" in social media environments.

\section{Literature Review}

Goffman (1974) defined "the frame" as the organising principle of news; it can be understood as an ideological and interpretive frame that enables journalists to report on issues or as a way for media to report on certain events, groups, individuals, or institutions with positive or negative attributes (Fourie, 2001). The news frame affects the definition of problems, provides causal explanations, and puts forward moral evaluations and suggestions (Entman, 1993). Some believe that the frame is also regarded as an essential "central idea" in understanding and describing the relevant events of a problem and indirectly suggesting how it should be dealt with (Gamson
\& Modigliani, 1989). The media frame specifically refers to "continuous cognitive, interpretive and presentation patterns, including selection, emphasis, and exclusion, through which news editors usually organise discourse" (Gitlin, 2003, p. 7). Therefore, news frames are susceptible to ideology and one-sided news/media organisations (Shoemaker \& Reese, 2013).

Newspapers are considered a suitable medium for framing analysis (Linstrom \& Marais, 2012) and the portion of the media most responsible for a society's culture and emotion (Reah, 2002) as well as for the discourse that power holders (Fairclough, 2013) use to express the culture and events of a specific society. Newspapers construct and disseminate various news through frames to enhance readers' social and political awareness (Fowler, 2013; Van Dijk, 1993).

\subsection{Media and the Arab Uprisings}

The Arab uprisings refer to a series of anti-government movements with the themes of "democracy," "people's livelihood," "citizen empowerment," and "overthrowing authoritarian governments" in Arab countries in the early 2010s, which has had a far-reaching impact on the Arab world, as well as the international geostrategic pattern (Badr, 2021; Derichs \& Demmelhuber, 2014; M. Lynch, 2013). The political power of some relevant countries is still in turmoil, and everything has not yet completely ended.

There are two kinds of research on media and the Arab uprisings: One kind discuss media and mobilisation. Some argue that digital media technology has played an essential role in the communication, coordination, and guidance of this rising tide of opposition (Bennett \& Segerberg, 2012; Castells, 2015; Howard \& Hussain, 2013; Papacharissi, 2016). Others argue that the role of social media should not be overemphasised, and the impact of social media must be related to how such media platforms adapt to the broader media ecology and social and political structures (Hamanaka, 2020; Robertson, 2015). Some studies have found that the changes in the information environment have changed individual competencies, the ability to organise for collective action, and the transmission of information from the local to the international level. The new and old media are interrelated (M. Lynch, 2013), and the coverage transferred the issue's salience from new media into mainstream media, thus reaching wider non-politicised audiences (Badr, 2021). The long-term evolution of a new kind of public sphere may matter more than immediate political outcomes (M. Lynch, 2011).

Another strand of literature identifies reporting on the revolutionary movement and studies how different countries and media have framed Arab uprisings (Hamdy \& Gomaa, 2012; Khamis \& Vaughn, 2011). The state as a frame of reference is important for understanding the nature of political change (Derichs \& Demmelhuber, 2014). The results show that different media have 
chosen different reporting frames (Bruce, 2014). Some examine how traditional and non-traditional media reported on Egyptian protests to determine whether the media influenced the protests (Harlow \& Johnson, 2011). Others explore the differences between media in Western countries and that in other regions regarding how they covered news on Arab Uprisings and what frames they used.

\subsection{China's West Asia and North Africa Policy and Chinese Media}

Echoing China's cultural tradition of having a peaceful and harmonious civilisation (Qin, 2018) and the peaceful rise strategy, the core idea of China's foreign policy is guided by principles of trust, forbearance, reciprocity, and equity. China still adheres to the basic principle of non-interference in its foreign policy (J. Zhang, 2015). In the era of President Xi Jinping, the "One Belt, One Road" initiative has become one of China's major diplomatic strategies (S. I. Chan \& Song, 2020). There is widespread cooperation between China and West Asia and North Africa (WANA). The conflicts in the Arab world put China's political relationships at risk and threaten its economic interests (Singh, 2016).

The WANA region has always been a key strategic focus of the US, Europe, and Russia, while to China, it is not as crucial as its neighbours in the Asia-Pacific and other regions (Chaziza, 2013). Although China's foreign policy towards WANA has undergone several significant changes since 1949 (Horesh, 2016), the country's relationship with states there is now pragmatic. China's WANA policy highlights the country's persistence in identifying as a state of the Global South (Liu et al., 2020) and has played as a regional conflict mediator (Chaziza, 2018). China has always stood for a non-interference policy, advocating political dialogue and the peaceful settlement of relevant issues (Bai, 2012). This kind of intervention in WANA conflicts is mainly related to keeping the peace, managing conflict, and securing regional security (Shichor, 2013).

For a long time, reporting on international issues has often been regarded as a barometer of China's internal affairs and diplomacy, highly tied to national diplomacy and external publicity (Shen, 2004; Shirk, 2007; H. Wang, 2003; J. Wang \& Wang, 2014; S. Zhao, 2013). Although it has been loosened in recent years, its characteristics have not changed. In addition, Chinese media reports on WANA are deeply influenced by ethnic groups, religions, class struggles, international relations, and revolutionary theories. They are related to geopolitics, economy, and regional security (Cheng \& Shi, 2009; d'Hooghe, 2007; Meidan, 2006; Sun \& Zoubir, 2018).

\subsection{Chinese Media and the Arab Uprisings}

Literature on China's media system and communication process include the Chinese system of propaganda and media control (Brady, 2009; Qiu, 1999; Shambaugh, 2017), the fusion of party-state powers and market rationality in the Chinese media (Barmé, 1999; T. V. Lee \& Li, 2000; Y. Zhao, 2009), the emergence of China's "civil society" and the pursuit of news specialisation (J. M. Chan et al., 2004; D. C. Lynch, 1999; Pan \& Chan, 2003; Pan \& Lu, 2003), etc.

According to the Cyberspace Administration of China (2017), Chinese media are regulated by the government to some extent (Guo, 2019). Official news venues such as the People's Daily and Xinhua News Agency are the mouthpieces of the Communist Party of China, representing the views of national leadership (Stockmann \& Gallagher, 2011). People's Daily is the official newspaper of the Central Committee of the Communist Party of China. Because of this status and the special relationship between government and Central Committee, documenting the frequency and content of articles in the People's Daily is considered an effective means of gauging the current leadership's level of interest and views on a particular topic (Hoddie, 2006).

Business portals and social media generally have national audiences and are not very different from news websites and social media in other parts of the world (Kilgo et al., 2018). Since 2010, major commercial news sites have expanded their editorial teams by recruiting many senior editors and journalists from traditional media. Editors of commercial news websites publish or report on user-generated content from other online platforms or contribute original news stories by directly interviewing online users. Due to the financial independence (S. I. Zhang, 2012) of these portals and social media platforms, their news reports may deviate from official discourse to some extent (C. C. Lee et al., 2007). Caixin $\mathrm{Net}$ is a well-known financial and economic news website that is supported by subscriptions and professionally operated to satisfy the social elites' information needs (Ji et al., 2016). Caixin Net was founded by Ms Hu Shuli and officially launched in 2010. Publicly available information shows that the largest shareholder of Caixin Net is a private enterprise, accounting for about $23.4 \%$ of its shares (Tianyancha, 2021).

Some argue that from the very beginning, Beijing tried to curb the spread of information to its people through the Internet, which is interpreted as the government's efforts to prevent what was happening in the Arab uprisings movement from happening in China ( $\mathrm{Ha} \&$ Shin, 2019). However, the frames of the Chinese media seem to be inconsistently portrayed in many studies. One study showed that mainland Chinese media chose not to take a news perspective that was favourable toward the Arab uprisings (Du, 2016). Another piece of research showed that compared with Al Jazeera and the BBC, China Daily's website, without relying exclusively on the content of the official press agency of the People's Republic of China, Xinhua News Agency, acted like a Western-type news media (Karyotakis et al., 2017). A study stated that China Daily used the protest paradigm to belittle 
the importance of the Arab uprisings (Ha \& Shin, 2019). These different conclusions make this study even more valuable, begging the question: Why do Chinese media have such different views on the Arab uprisings? Are there political considerations behind these views?

\section{Study Aim and Research Questions}

As Graber (2003, p. 140) pointed out, "many extensive and clear judgments about the substantive content of mass media are still made without analysing the actual content of these media." This study investigates the frame used to report the uprisings in the past ten years. It discusses the position of this topic in the public discourse system and how the frame represents Chinese media, Chinese people, and the Chinese government. Based on the above information, the research questions we posed are:

1. How did selected Chinese media frame the Arab uprisings?

2. What are the differences between People's Daily's and Caixin Net's reporting on the Arab uprisings?

3. How have Chinese "media frames" changed over the decade, from 2011 until 2021?

4. What is the relationship between Chinese media coverage of the Arab uprisings and the Chinese government's WANA policy?

\section{Methods}

\subsection{Media and Material Samples}

The material samples include all journalistic articles such as news stories, editorials, interviews, feature stories, columns, and commentaries published from People's Daily and Caixin Net, and statements from the Chinese Foreign Ministry from December 2010 to March 2021. Using the words "Arab uprisings," "Tunisia," "Egypt," "Mubarak," and "protest" as keywords, we searched the People's Daily database and obtained valid samples ( $n=77$ ). We searched the Caixin Net database and acquired valid samples $(n=148)$. We analysed relevant statements by the Chinese Foreign Ministry to explore the government's foreign policies and practical actions in the WANA during the Arab uprisings. We chose Tunisia, Egypt, Libya, and Syria as related countries because Tunisia experienced the first outbreak of the Arab uprisings, followed by Egypt, one of the most prominent countries in the WANA region. Since 2011, Syria and Libya have been in an ongoing armed conflict and civil war. Searches for the four countries were conducted on the Ministry of Foreign Affairs website, and valid samples ( $n=131$ ) were obtained after screening.

\subsection{Coding}

Two researchers screened and categorised articles according to coding themes. The coding book contains variables that considered the basic data of the articles, e.g., the frame, issue, news type, news source, subject, and position of the articles, making a total of six variables. Each story was coded as one of 4-5 possible categories outlined in previous studies (Groshek, 2008; Natarajan \& Hao, 2003; Weaver et al., 2009). The variables and categories are shown in Table 1.

According to the coding book, the coding results of People's Daily and Caixin Net are described in Table 2.

Concerning statements by the Chinese Foreign Ministry, we chose the policies, subjects, issues, and propositions of the material, making a total of four variables as shown in Table 3. In short, policies include positive, neutral, and negative ones; subject included international organisation, the ruling party, the opposition, and the political situation; issues included the economy, politics, security, and people's livelihoods; propositions included peaceful settlement, political consultation, mediation, anti-violence, and rebuilding.

\subsection{Reliability}

Two coders were trained before jointly coding the first $20 \%$ of the materials and used a formula to test the reliability. Intercoder reliability scores were calculated using Holsti's coefficient of reliability (Holsti, 1969) for coding outcomes. The scores ranged from $90 \%$ to $100 \%$, with Holsti's, indicating high coding reliability. When different codes appeared, the coders chose a more suitable code after discussion and modification.

\section{Findings}

\subsection{Declining Media Attention to the Influence of Arab Uprisings}

Overall, the attention of the Chinese media to Arab uprisings has declined over the past ten years. The number of sources in the three groups all showed downward trends (see Figure 1). The number of sources from Caixin Net and the Chinese Foreign Ministry showed the most obvious decline. The number of reports from Caixin Net ( $n=148$ ) is almost twice that of People's Daily $(n=77)$.

People's Daily emphasised the grand narrative of the change in the Arab region and attributed the movement to politics, economy, and human rights (see Figure 2). It mainly reported on Arab uprisings using disaster framing $(37.66 \%)$ and contrasting framing $(23.38 \%)$, with small variations over time in the number of articles using these types of framing. People's Daily hardly described the mass movement directly in the first two years. On August 29th, 2011, the first report in People's Daily that directly mentioned "Arab uprisings" used "uncertainty," "impossible to predict accurately," and "worrying" to express concern about this mass revolutionary movement (Zhong, 2011). When discussing the practical significance of political system reconstruction in WANA, People's Daily took the Western-style 
"democratic system" as contrast and put forward the viewpoint that "a specific political system is the product of a specific cultural soil" (Zhong, 2011, p. 3).

Caixin Net used the movement as the background. Over the past ten years, Caixin Net's reporting has mainly used contextual framing (79.05\%), followed by disaster framing $(12.84 \%)$. In contrast, Caixin Net reported the Arab uprisings from a specific and personalised perspective and attributed the mass movement to "people's dissatisfaction with living standards, police violence, high unemployment rate, and poor human rights situation" (Yu, 2011, p. 1).

\subsection{Framing and Balance}

The two media mainly focused on political issues (see Figure 3). Security issues were the second focus of People's Daily, while economic issues were Caixin Net's second focus. Caixin Net consistently focused on political issues, while the focus of People's Daily varied.

Table 1. The category and description of coding.

\begin{tabular}{|c|c|c|}
\hline \multicolumn{2}{|l|}{ Category } & \multirow{2}{*}{$\begin{array}{l}\text { Description } \\
\text { Emphasising the differences between the Chinese and the international } \\
\text { systems }\end{array}$} \\
\hline Frame & Contrasting frame & \\
\hline & Disaster frame & Emphasising violent regional conflicts and the destruction of people's lives \\
\hline & Critical frame & $\begin{array}{l}\text { Focusing on an issue that was wrong and needed to be changed or } \\
\text { supervised/monitored }\end{array}$ \\
\hline & Accountability frame & $\begin{array}{l}\text { Emphasising that China should learn from the experiences and lessons } \\
\text { regarding certain topics }\end{array}$ \\
\hline & Contextual frame & Presenting historical events as a background \\
\hline \multirow[t]{4}{*}{ Issue } & Economy & $\begin{array}{l}\text { Involving economic issues, economic conferences held by the government } \\
\text { and business enterprises, and daily production and operation activities }\end{array}$ \\
\hline & Politics & Involving political reform, political systems, geopolitics, and ideology \\
\hline & Security & Involving regional wars, armed conflicts, illegal immigrants, and refugees \\
\hline & People's livelihoods & $\begin{array}{l}\text { Including human rights issues, civil rights, and the fight for the rights of } \\
\text { vulnerable groups }\end{array}$ \\
\hline \multirow[t]{4}{*}{ News type } & News & Which is short in length and reports on events within the last two days \\
\hline & News story & $\begin{array}{l}\text { Including news about influential and famous people and events in local areas } \\
\text { in which journalists often report details and changes in Arab uprisings by } \\
\text { collecting materials and selecting typical examples }\end{array}$ \\
\hline & In-depth report & $\begin{array}{l}\text { Involving reporters deeply immersed in the local scenes to investigate and } \\
\text { selectively expose the complex relationships among different news reports }\end{array}$ \\
\hline & Commentary & Articles written by observers, including the dialogues and interviews of scholars \\
\hline \multirow[t]{5}{*}{ News source } & $\begin{array}{l}\text { Foreign government/ } \\
\text { organisation }\end{array}$ & \\
\hline & Foreign media & \\
\hline & Local people & \\
\hline & Chinese journalists & \\
\hline & Scholars/researchers & \\
\hline \multirow[t]{5}{*}{ Subject } & International subjects & \\
\hline & National subjects & \\
\hline & Enterprises & \\
\hline & People & \\
\hline & Politicians & \\
\hline \multirow[t]{3}{*}{ Position } & Positive & Supporting, affirming, and praising the Arab uprisings \\
\hline & Neutral & No apparent positive or negative position or the position is impossible to judge \\
\hline & Negative & $\begin{array}{l}\text { Expressing opposition or criticism towards Arab uprisings and arguing that it } \\
\text { had adverse consequences }\end{array}$ \\
\hline
\end{tabular}


Table 2. The coding of data from Caixin Net $(\mathrm{n}=148)$ and People's Daily $(\mathrm{n}=77)$.

\begin{tabular}{|c|c|c|c|}
\hline Coding & & $\begin{array}{c}\text { Caixin Net } \\
\text { (number, percentage } \\
\text { to the total) }\end{array}$ & $\begin{array}{c}\text { People's Daily } \\
\text { (number, percentage } \\
\text { to the total) }\end{array}$ \\
\hline \multirow[t]{5}{*}{ Frame } & Contrasting frame & $2 \mid 1.35 \%$ & 18 | 23.38\% \\
\hline & Disaster frame & 19 | $12.84 \%$ & $29 \mid 37.66 \%$ \\
\hline & Critical frame & $1 \mid 0.68 \%$ & 13 | $16.88 \%$ \\
\hline & Accountability frame & $9 \mid 6.08 \%$ & 13 | $16.88 \%$ \\
\hline & Contextual frame & 117 | 79.05\% & $4 \mid 5.19 \%$ \\
\hline \multirow[t]{4}{*}{ Issue } & Economy & 32 | $21.62 \%$ & $14 \mid 18.18 \%$ \\
\hline & Politics & 89 | 60.14\% & 35 | 45.45\% \\
\hline & Security & $5 \mid 3.38 \%$ & 18 | $23.38 \%$ \\
\hline & People's livelihoods & $22 \mid 14.86 \%$ & $10 \mid 12.99 \%$ \\
\hline \multirow[t]{4}{*}{ News type } & News & $10 \mid 6.76 \%$ & $4 \mid 5.19 \%$ \\
\hline & News story & $88 \mid 59.46 \%$ & 22 | $28.57 \%$ \\
\hline & In-depth report & $8 \mid 5.41 \%$ & $11 \mid 14.29 \%$ \\
\hline & Commentary & 42 | $28.38 \%$ & 40 | 51.95\% \\
\hline \multirow[t]{5}{*}{ News source } & Foreign government or organisation & 43 | 29.05\% & $8 \mid 10.39 \%$ \\
\hline & Foreign media & $4 \mid 2.70 \%$ & 6 | $7.79 \%$ \\
\hline & Local people & $4 \mid 2.70 \%$ & 9 | $11.69 \%$ \\
\hline & Chinese journalists & $61 \mid 41.22 \%$ & $12 \mid 15.58 \%$ \\
\hline & Scholars/researchers & $36 \mid 24.32 \%$ & $42 \mid 54.55 \%$ \\
\hline \multirow[t]{5}{*}{ Subject } & International subjects & 79 | 53.38\% & 35 | 45.45\% \\
\hline & National subjects & 33 | 22.30\% & 19 | 24.68\% \\
\hline & Enterprises & $4 \mid 2.70 \%$ & $3 \mid 3.90 \%$ \\
\hline & People & $16 \mid 10.81 \%$ & $20 \mid 25.97 \%$ \\
\hline & Politicians & $16 \mid 10.81 \%$ & $0 \mid 0 \%$ \\
\hline \multirow[t]{3}{*}{ Position } & Positive & $3 \mid 2.03 \%$ & $0 \mid 0 \%$ \\
\hline & Neutral & 102 | 68.92\% & 22 | $28.57 \%$ \\
\hline & Negative & 43 | 29.05\% & 55 | 71.43\% \\
\hline
\end{tabular}

Table 3. The coding of statements of the Chinese Foreign Ministry $(n=131)$.

\begin{tabular}{llr}
\hline Category & & Chinese Foreign Ministry (number, percentage to the total) \\
\hline Policy & Positive & $50 \mid 38.17 \%$ \\
& Neutral & $68 \mid 51.91 \%$ \\
& Negative & $13 \mid 9.92 \%$ \\
\hline Subject & International organisations & $29 \mid 22.14 \%$ \\
& The ruling party & $36 \mid 27.48 \%$ \\
& The opposition & $10 \mid 7.63 \%$ \\
& The political situation & $56 \mid 42.75 \%$ \\
\hline Issue & Economy & $5 \mid 3.82 \%$ \\
& Politics & $104 \mid 79.39 \%$ \\
& Security & $15 \mid 11.45 \%$ \\
& People's livelihoods & $7 \mid 5.34 \%$ \\
\hline Proposition & Peaceful settlement & $34 \mid 25.95 \%$ \\
& Political consultation & $29 \mid 22.14 \%$ \\
& Mediation & $17 \mid 12.98 \%$ \\
& Anti-violence & $26 \mid 19.85 \%$ \\
& Rebuilding & $25 \mid 19.08 \%$ \\
\hline
\end{tabular}




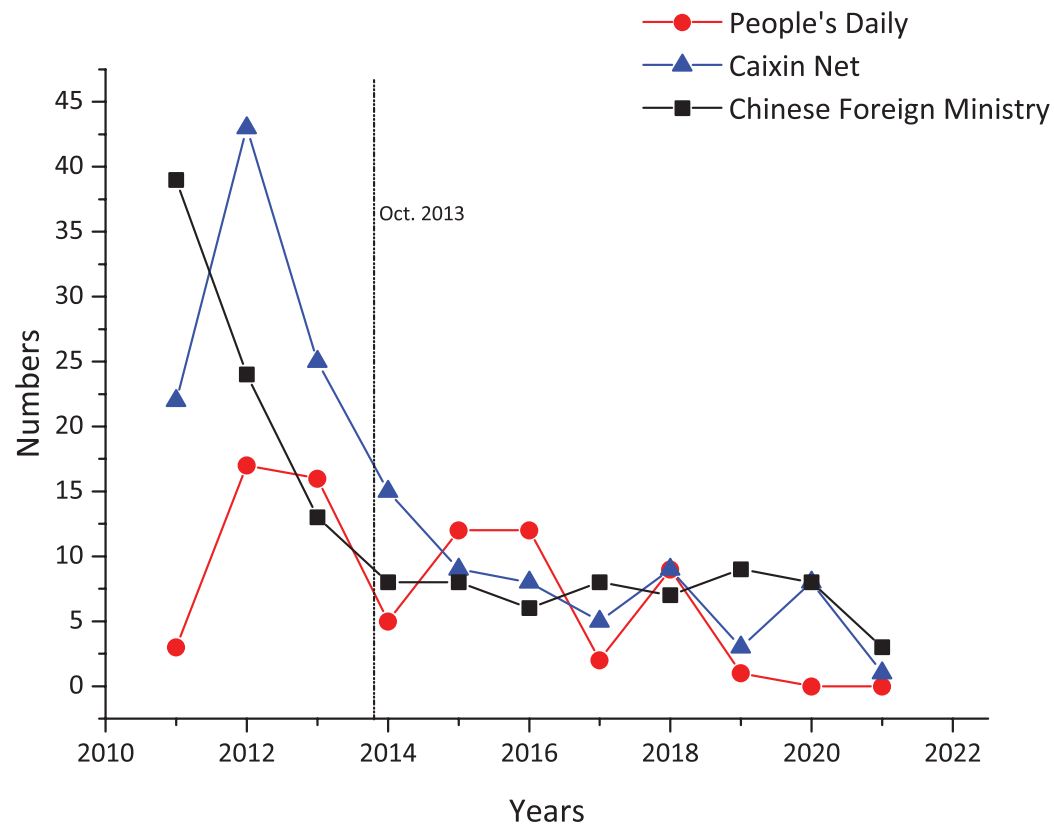

Figure 1. Changes in the number of articles from the two media platforms and of statements from the Chinese Foreign Ministry.

The two media platforms consistently but infrequently covered economic issues. Finally, People's Daily was more focused on security and livelihood issues than Caixin Net.

People's Daily emphasised the regime's subversion by the Arab uprisings and the breaking of the Arab world's original regional and political order. The security issues (23.38\%) show more concern about the chaos and bloodiness of the movement. People's livelihood issues (12.99\%) mainly describe the difficulty of life from the residents' perspectives.

In contrast, Caixin Net reports on the political issues (60.14\%) of the Arab uprisings mainly focus on two aspects. The first is as the background element of the evolution of political patterns in the WANA region. The second is a tool to measure the positions of global politicians. The second issue is the economy (21.62\%), which mainly involves global energy problems and economic recession. In addition, it also reports the gap between the rich and the poor and income problems within Arab countries.

As shown in Figure 4, People's Daily paid more attention to the impact of the Arab uprisings on local people. Caixin Net was more inclined to cover politicians. At the beginning of the Arab uprisings, both media were more likely to publish articles about international subjects than towards the end of the study period, as Caixin Net's coverage of such subjects gradually decreased, while that of the People's Daily varied.

As shown in Figure 5, People's Daily took a negative position towards the Arab uprisings (71.4\%), especially after the Chinese government publicly stated its position,
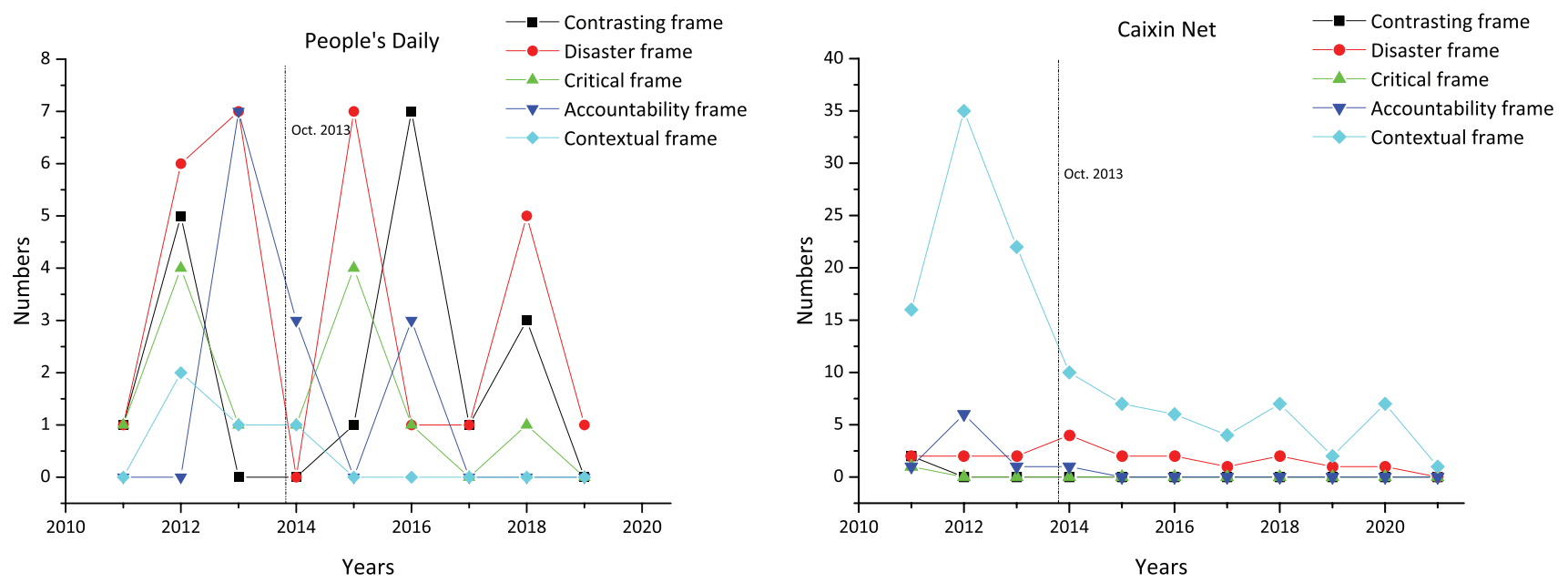

Figure 2. Comparing the coverage frames in People's Daily and Caixin Net. 

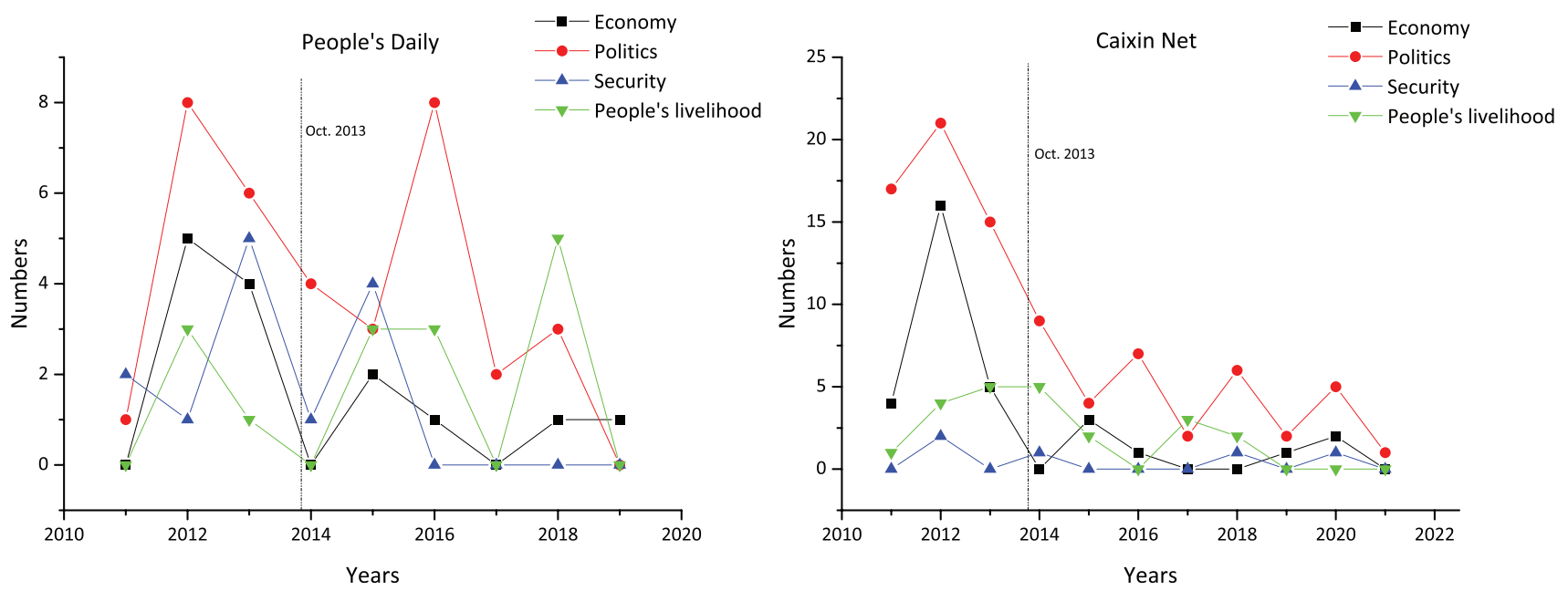

Figure 3. Changes in the number of issues reported on by the People's Daily and Caixin Net.

emphasising the social unrest and sustained economic decline brought about by the Arab uprisings. Caixin Net was more neutral, emphasising that the Arab uprisings had brought about significant changes and greatly influenced life in the Arab world while avoiding obvious positions (68.9\%). The only three articles that reported positively on the Arab uprisings were from Caixin Net and quotes from foreigners.

\subsection{The Media Agenda in Relation to Geopolitics in WANA (2011-2021)}

The media agenda is closely related to Chinese politicians' internal affairs, diplomacy, and geopolitics. From the perspective of China, on January 19th, 2012, Premier Wen Jiabao attended the fourth China-Arab Business Conference in Sharjah, United Arab Emirates, and systematically explained China's neutral policies towards the turmoil in the WANA region for the first time. Both People's Daily and Caixin Net had similar positions in 2012. From January to March 2012, People's Daily published nine articles that took a neutral position when analysing the Arab uprisings and the reasons for its outbreak.

On May 13th, 2016, Chinese Foreign Minister Wang Yi visited Tunisia, the birthplace of the Arab uprisings movement, and met with Tunisian President Essebsi and Prime Minister Essid. Following his visit, Minister Wang Yi accepted an exclusive interview with the media and talked about WANA. This also set the tone for the content of subsequent reports published by the People's Daily. China hopes to establish long-term cooperative relations with the Arab region and maintain stable economic exchange.

From an international perspective, a "colour revolution" broke out in Ukraine in 2014. People's Daily cited common patterns in these changes and negatively stated international support for these activities. In 2015, coverage of Arab uprisings increased again. The primary reporting frames were disaster and criticism, and the coverage included political and regional security issues. In 2015, a civil war broke out in Yemen, and the Chinese government and the People's Liberation Army carried out a large-scale evacuation of Chinese nationals living

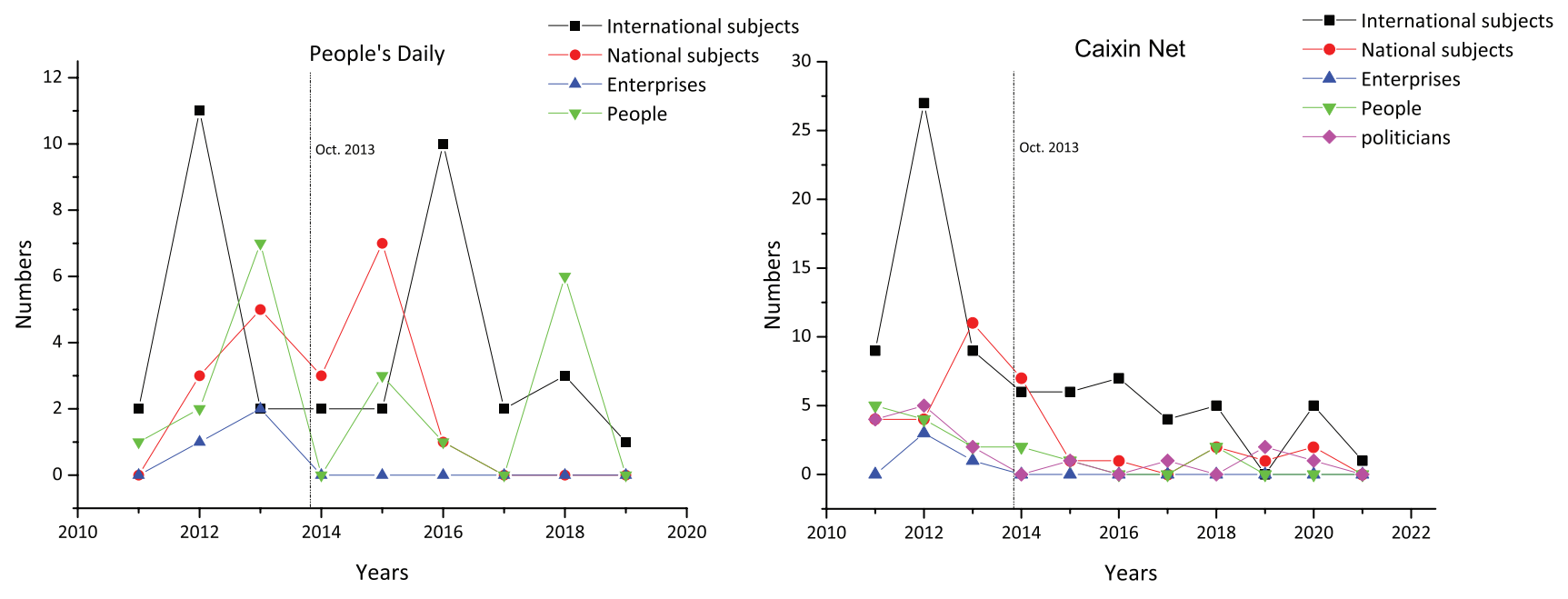

Figure 4. Changes in the number of subjects covered by the People's Daily and Caixin Net. 

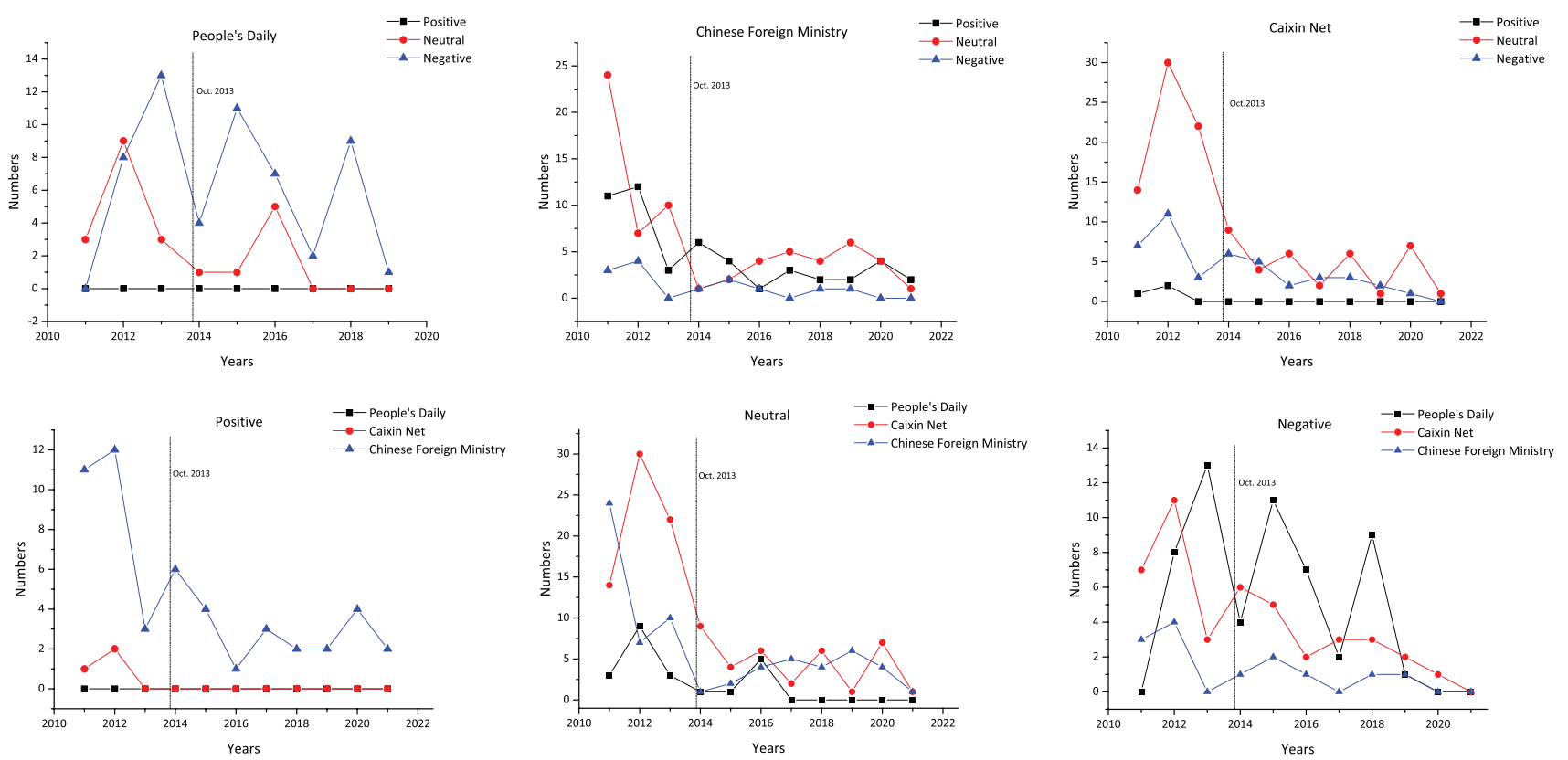

Figure 5. Positions towards the subjects discussed in the People's Daily, Caixin Net, and statements from the Chinese Foreign Ministry from 2010 to 2021.

in the country. The main findings can be summarised as follows: The social movement profoundly impacted the regional situation and political environment, but regional economic development and individual people's lives were not improving.

At the end of 2018, US President Donald Trump announced the withdrawal of troops from Syria. Syrian refugees living in foreign countries began to return home. Although the reporting frame was still dominated by a disaster and contrast frame during this period, following the war, people accounted for a more significant proportion of the news sources and subjects of news articles, and the Chinese media were more inclined to explore the Arab uprisings from the refugee perspective.

In fact, unlike the strategic contraction of the US and the active involvement of the European Union in the

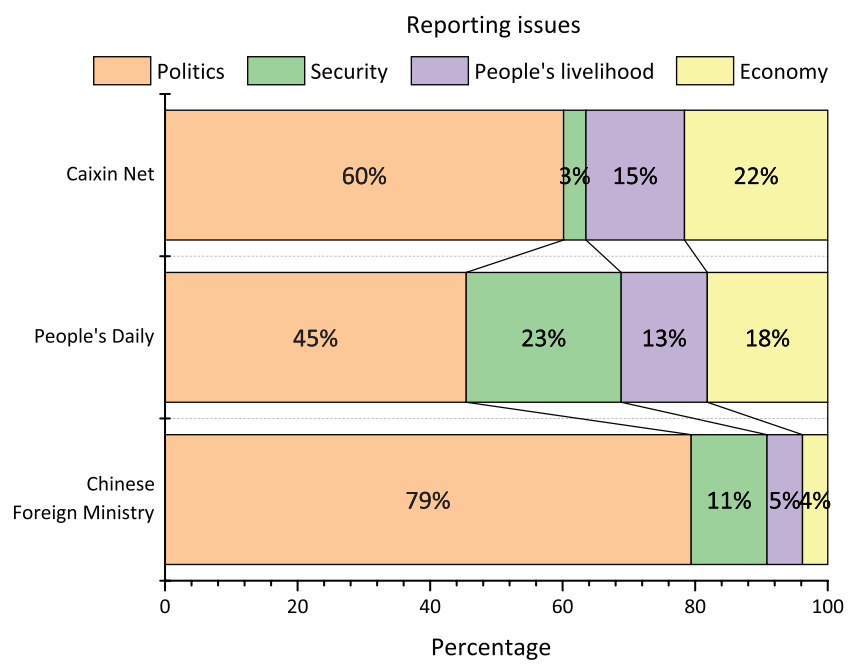

Arab region, China still adopts a longer-term and more basic strategic means for Arab countries and only wants to maintain friendly relations with countries in the Arab region and expand its right to express its views.

\subsection{Chinese Media and the Statements and Agenda of the Chinese Foreign Ministry}

Content of the Chinese Foreign Ministry statements can be identified into four categories: policies, subjects, issues, and propositions. As shown in Figure 6, the issues and policies differed most between the two media. There were five subcategories of propositions, and the statements most frequently covered social movements, including "anti-violence" (21.4\%) and "peaceful settlement" (24.4\%), which revealed China's consistent

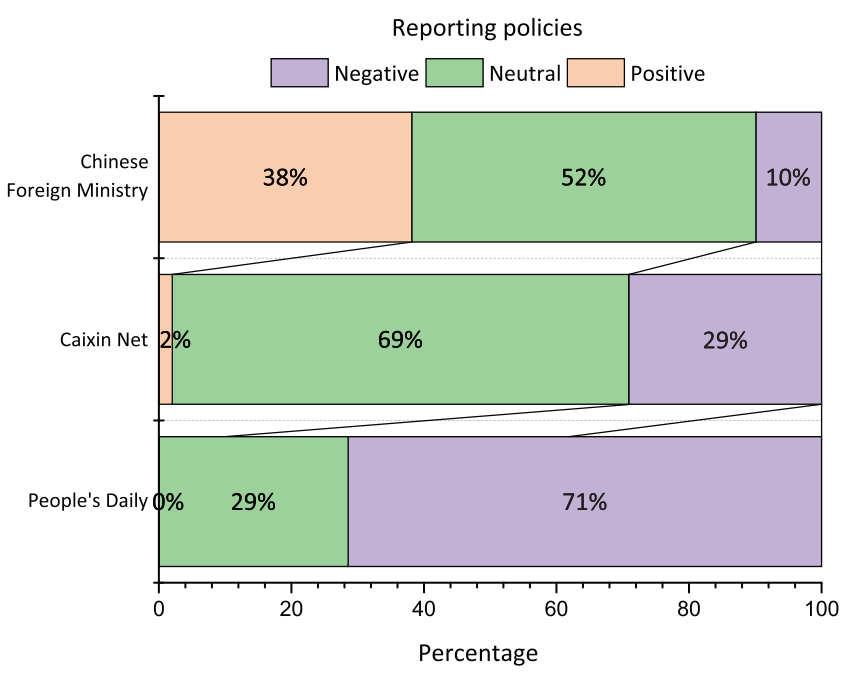

Figure 6. The percentage of reporting issues and policies of People's Daily, Caixin Net, and the Chinese Foreign Ministry. 
position in dealing with foreign affairs. The ministry's statements also discuss specific measures such as political consultations $(20.61 \%)$ and mediation by international organisations such as the United Nations (12.98\%).

Among the four subcategories of the statements' subjects, political situations account for the most proportion (42.75\%), followed by the ruling party ( $26.72 \%)$, and international organisations (22.14\%), which once again shows that the regional political situation is the focus of the Chinese Foreign Ministry's attention. Only $6.87 \%$ of the statements dealt with opposition parties, showing that the Chinese Foreign Ministry has little direct interest in opposition parties in the WANA region.

Concerning issues, political issues were the most commonly discussed (79.39\%), followed by regional security issues (11.45\%), livelihood issues (5.34\%), and economic issues (3.82\%). This shows that among the issues in the Arab region, especially from 2011 to 2013, the Chinese government was most concerned with political issues.

Regarding policies, neutral/concerned policies accounted for the most significant proportion of policies expressed in the statements (51.91\%), followed by positive $(38.17 \%)$ and negative policies (9.92\%).

Through cross-analysis, one can see that the Chinese Foreign Ministry, the People's Daily, and Caixin Net had significant correlations in terms of the issues $\left(x^{2}(d f=6)\right.$ $=50.936, p<0.05$ ) and the policies (total $>320$ (356) for $4 \mathrm{df}, p<0.05)$. It shows that Chinese media follow the statements and agenda of the Chinese Foreign Ministry.

To test whether changes in the Chinese government's policies influence the way Chinese media reported on the Arab uprisings, we examined Chinese policies before and after October 2013 when China proposed the "One Belt, One Road" initiative officially, to find that the government responses and news reporting showed no obvious change.

\section{Discussion and Conclusion}

The study selected the most influential official media (People's Daily) and one influential commercial media (Caixin Net) to analyse China's coverage of the Arab uprisings. We conducted a content analysis of 356 separate documents to identify and categorise the way stories were framed. More specifically, our analyses focused on four aspects: the general way in which the uprisings were framed; the differences between Chinese media reporting on the uprisings; how the frames have changed over a decade from 2011 until 2021; the relationship between Chinese media coverage of the uprisings and the Chinese government's WANA policy.

We found that the number of reports on Arab issues by the two media was correlated. Both them and the Chinese foreign ministry show a decreasing trend over the past decade, focusing mainly on the international and domestic subjects related to political issues. However, there are differences within Chinese media.
First, the People's Daily has a small amount of information, which may only account for $20-30 \%$ of Caixin Net. Second, People's Daily used the disaster frame while Caixin Net mainly used the contextual frame. Third, the position and tendency of People's Daily were close to the official policy and mainstream ideology advocated by the government, and Caixin Net is more independent. This difference is mainly due to the reform of the cultural system, especially the transition from cultural institutions (shiye) to commercial industries (chanye; see Keane \& Zhao, 2014).

Chinese media are different from Arabic and Western media in observing and explaining the Arab uprisings (Du, 2016; Guzman, 2016; Halverson et al., 2013; Hamdy \& Gomaa, 2012). This difference is reflected in the initial characterisation of the movement and the frame and narrative discourse. Specifically, it is mainly reflected in two points:

First, the belief and value shaping in Arab Uprisings are different. CNN and Fox News described the Arab Uprising as involving "people seeking democracy" (Guzman, 2016), some Arab media described it as "forces for social mobilisation and political change" (Halverson et al., 2013, p. 312), whereas Chinese media described it as "causing great damage to the economy" (Jiao et al., 2012, p.23). Frames are powerful because they impart meaning (Gamson \& Modigliani, 1989, p. 3). All of them are aimed at making the reports resonate effectively in their regions and strengthening their legitimacy and attractiveness. By choosing some aspects of revolutionary reality, the media text limits the audience's interpretation. Especially in international conflicts, the national media may have different interpretations for the audience.

Second, the scheme descriptions of Arab uprisings are different. Chinese media did not mention the specific strategies of the uprisings. However, social media and independent media from Arabic more clearly described the protest and reform scheme, scale of mobilisation, and specific movement slogan (Hamdy \& Gomaa, 2012). Western media believe that the Arab uprisings is the product of "resentment against the government" (Lim, 2012). This long resentment encourages individuals to get together, protest against the status quo and find a way out. The appeal of this mass movement was constructed as a request for a thorough change in the whole social structure, and there was a political appeal from the beginning (Smith \& Fetner, 2009).

As Fenton (2008) thinks, it combines many vital elements, such as cultural resonance, the historical narration of inheriting a common heritage, and efforts to solve the past moral, ethical, and national crises. Media provide communication opportunities, necessary connections, and shared political imagination. We believe that this difference originates from cultural, regional politics, and other factors.

Media representations are complex social constructions (Shoemaker \& Reese, 2013), and it is likely that multiple factors, including source selection, first-hand 
experience, and political ideology shaped media frames of revolution participants (Guzman, 2016). This study demonstrates that Chinese media portrayals of the WANA region are simultaneously dynamic. The Chinese media's shaping of the Arab uprisings depends on China's diplomatic stance and international political image and is influenced by international public opinion. In the post-Arab uprisings stage, Chinese media are generally pragmatic and more concerned about reconstruction, political stability, social security, and the recovery of people's livelihoods.

\section{Acknowledgments}

The authors would like to thank Raquel Silva, academic editors Hanan Badr, Lena-Maria Möller, and the reviewers for their valuable support. This article has been produced as part of the major project of the National Social Science Fund of China, Research on the Establishment of Omnimedia Communication System (Grant No. 20ZDA057).

\section{Conflict of Interests}

The author declares no conflict of interest.

\section{Disclaimer}

The Arab-German Young Academy of Sciences and Humanities (AGYA) is supporting the thematic issue "Ten Years after the Arab Uprisings: Beyond Media and Liberation," edited by AGYA alumna Hanan Badr (Gulf University of Science and Technology, Kuwait) and AGYA member Lena-Maria Möller (Max Planck Institute for Comparative and International Private Law, Germany). AGYA is funded by the German Federal Ministry of Education and Research (BMBF). The authors remain solely responsible for the content and recommendations provided in this publication, which do not reflect the positions of AGYA or any of its funding partners.

\section{References}

Aarts, P., \& Cavatorta, F. (2013). Civil society in Syria and Iran: Activism in authoritarian contexts. Lynne Rienner Publishers.

Akhavan-Majid, R., \& Ramaprasad, J. (1998). Framing and ideology: A comparative analysis of US and Chinese newspaper coverage of the fourth United Nations conference on women and the NGO forum. Mass Communication and Society, 1(3/4), 131-152. https://doi.org/10.1080/15205436.1998.9677853

AlMaghlouth, N., Arvanitis, R., Cointet, J. P., \& Hanafi, S. (2015). Who frames the debate on the Arab uprisings? Analysis of Arabic, English, and French academic scholarship. International Sociology, 30(4), 418-441. https://doi.org/10.1177/0268580915580 157
Badr, H. (2021). Before the "Arab Spring": How challengers pushed counter-issues in Egypt's hybrid media system. Media, War \& Conflict, 14(4), 522-541. https://doi.org/10.1177/1750635219894 611

Bai, T. (2012). China: The political philosophy of the middle kingdom. Bloomsbury Publishing.

Barmé, G. R. (1999). CCP ${ }^{\mathrm{TM}}$ \& ADCULT PRC. The China Journal, 1(41), 1-23. https://doi.org/10.2307/2667585

Baum, M. A., \& Potter, P. B. (2008). The relationships between mass media, public opinion, and foreign policy: Toward a theoretical synthesis. Annual Review of Political Science, 11(1), 39-65. https://doi.org/ 10.1146/annurev.polisci.11.060406.214132

Bennett, W. L., \& Segerberg, A. (2012). The logic of connective action: Digital media and the personalization of contentious politics. Information, Communication \& Society, 15(5), 739-768. https://doi.org/10.1080/ 1369118X.2012.670661

Brady, A. M. (2009). Mass persuasion as a means of legitimation and China's popular authoritarianism. American Behavioral Scientist, 53(3), 434-457. https://doi. org/10.1177/0002764209338802

Bruce, M. D. (2014). Framing Arab Spring conflict: A visual analysis of coverage on five transnational Arab news channels. Journal of Middle East Media, 10(1), 1-26. https://doi.org/10.12816/0023470

Castells, M. (2015). Networks of outrage and hope: Social movements in the Internet age. John Wiley \& Sons.

Chan, J. M., Pan, Z., \& Lee, F. L. (2004). Professional aspirations and job satisfaction: Chinese journalists at a time of change in the media. Journalism \& Mass Communication Quarterly, 81(2), 254-273. https:// doi.org/10.1177/107769900408100203

Chan, S. I., \& Song, W. (2020). Telling the China story well: A discursive approach to the analysis of Chinese foreign policy in the "belt and road" initiative. Chinese Political Science Review, 5(3), 417-437. https:// doi.org/10.1007/s41111-020-00146-1

Chaziza, M. (2013). The Arab Spring: Implications for Chinese policy. Middle East Review of International Affairs, 17(2), 73-83.

Chaziza, M. (2018). China's mediation efforts in the Middle East and North Africa: Constructive conflict management. Strategic Analysis, 42(1), 29-41. https:// doi.org/10.1080/09700161.2017.1418956

Cheng, J. Y., \& Shi, H. (2009). China's African policy in the post-Cold War era. Journal of Contemporary Asia, 39(1), 87-115. https://doi.org/10.1080/ 00472330802506840

Cohen, B. C. (2015). Press and foreign policy. Princeton University Press. https://doi.org/10.1515/97814 00878611

Cottle, S. (2011). Media and the Arab uprisings of 2011. Journalism, 12(5), 647-659. https://doi.org/ 10.1177/1464884911410017

Cyberspace Administration of China. (2017). Internet news information service regulation. 
d'Hooghe, I. (2007). The rise of China's public diplomacy. Netherlands Institute of International Relations Clingendael.

Derichs, C., \& Demmelhuber, T. (2014). Monarchies and republics, state and regime, durability and fragility in view of the Arab Spring. Journal of Arabian Studies, $4(2)$, 180-194. https://doi.org/10.1080/21534764. 2014.974322

Du, Y. R. (2016). Same events, different stories: Internet censorship in the Arab Spring seen from China. Journalism \& Mass Communication Quarterly, 93(1), 99-117. https://doi.org/10.1177/107769901 5606670

Entman, R. M. (1993). Framing: Toward clarification of a fractured paradigm. Journal of Communication, 43(4), 51-58.

Fairclough, N. (2013). Critical discourse analysis: The critical study of language. Routledge.

Fenton, N. (2008). Mediating hope: New media, politics and resistance. International Journal of Cultural Studies, 11(2), 230-248. https://doi.org/10.1177/ 1367877908089266

Fourie, P. J. (Ed.). (2001). Media studies: Institutions, theories, and issues (Vol. 1). Juta and Company.

Fowler, R. (2013). Language in the news: Discourse and ideology in the press. Routledge.

Gamson, W. A., \& Modigliani, A. (1989). Media discourse and public opinion on nuclear power: A constructionist approach. American Journal of Sociology, 95(1), 1-37.

Gitlin, T. (2003). The whole world is watching: Mass media in the making and unmaking of the new left. University of California Press.

Goffman, E. (1974). Frame analysis: An essay on the organization of experience. Harvard University Press.

Graber, D. (2003). The media and democracy: Beyond myths and stereotypes. Annual Review of Political Science, 6(1), 139-160. https://doi.org/10.1146/ annurev.polisci.6.121901.085707

Groshek, J. (2008). Homogenous agendas, disparate frames: CNN and CNN International coverage online. Journal of Broadcasting \& Electronic Media, 52(1), 52-68. https://doi.org/10.1080/0883815070 1820809

Guo, L. (2019). Media agenda diversity and intermedia agenda setting in a controlled media environment: $A$ computational analysis of china's online news. Journalism Studies, 20(16), 2460-2477. https://doi.org/ 10.1080/1461670X.2019.1601029

Guzman, A. L. (2016). Evolution of news frames during the 2011 Egyptian revolution: Critical discourse analysis of Fox News's and CNN's framing of protesters, Mubarak, and the Muslim Brotherhood. Journalism \& Mass Communication Quarterly, 93(1), 80-98. https://doi.org/10.1177/1077699015606677

Ha, J. S., \& Shin, D. (2019). Portraying China as an alternative to U.S. hegemony: The China daily's framing of the Arab Spring. Atlantic Journal of Communication,
27(3), 200-215. https://doi.org/10.1080/15456870. 2019.1610764

Halbwachs, M. (2020). On collective memory. University of Chicago Press.

Halverson, J. R., Ruston, S. W., \& Trethewey, A. (2013). Mediated martyrs of the Arab Spring: New media, civil religion, and narrative in Tunisia and Egypt. Journal of Communication, 63(2), 312-332. https://doi. org/10.1111/jcom.12017

Hamanaka, S. (2020). The role of digital media in the 2011 Egyptia revolution. Democratization, 27(5), 777-796. https://doi.org/10.1080/13510347.2020. 1737676

Hamdy, N., \& Gomaa, E. H. (2012). Framing the Egyptian uprising in Arabic language newspapers and social media. Journal of Communication, 62(2), 195-211. https://doi.org/10.1111/j.1460-2466.2012.01637.x

Harlow, S., \& Johnson, T. J. (2011). The Arab Spring I Overthrowing the protest paradigm? How the New York Times, Global Voices and Twitter covered the Egyptian revolution. International Journal of Communication, 5(1). https://ijoc.org/index.php/ ijoc/article/view/1239

Hoddie, M. (2006). Minorities in the official media: Determinants of state attention to ethnic minorities in the People's Republic of China. Harvard International Journal of Press/Politics, 11(4), 3-21. https://doi.org/ 10.1177/1081180X06293728

Holsti, O. R. (1969). Content analysis for the social sciences and humanities. Addison Wesley.

Horesh, N. (Ed.). (2016). Toward well-oiled relations? China's presence in the Middle East following the Arab Spring. Springer. https://doi.org/10.1057/ 9781137539793

Howard, P. N., \& Hussain, M. M. (2013). Democracy's fourth wave? Digital media and the Arab Spring. Oxford University Press.

Ji, D., Hu, Z., \& Muhammad, Y. (2016). Neighboring competitor? Indian image in Chinese media. Global Media and China, 1(3), 234-250. https://doi.org/ $10.1177 / 2059436416668186$

Jiao, X., Yin, G., Huang, P., Mou, Z., \& Yang, X. (2012, December 21). Xiya beifei, dongdang rengzai chixu [In West Asia and North Africa, the turmoil continues]. People's Daily. http://data.people.com.cn/rmrb/pd. html

Karyotakis, M. A., Panagiotou, N., Antonopoulos, N., \& Kiourexidou, M. (2017). Digital media framing of the Egyptian Arab Spring: Comparing Al Jazeera, BBC and China Daily. Studies in Media and Communication, 5(2), 66-75. https://doi.org/10.11114/smc.v5i2. 2664

Keane, M., \& Zhao, E. J. (2014). The reform of the cultural system: Culture, creativity and innovation in China. In H. Lee \& L. Kim (Eds.), Cultural policies in East Asia (pp. 155-173). Palgrave Macmillan. https://doi.org/ 10.1057/9781137327772_10

Kelly, S., \& Smith, N. R. (2013). The EU's reaction to the 
Arab Spring: External media portrayals in China, India and Russia. European Foreign Affairs Review, 18(2), 217-234.

Khamis, S., \& Vaughn, K. (2011). Cyberactivism in the Egyptian revolution: How civic engagement and citizen journalism tilted the balance. Arab Media and Society, 14(3), 1-25.

Kilgo, D. K., Harlow, S., García-Perdomo, V., \& Salaverría, R. (2018). A new sensation? An international exploration of sensationalism and social media recommendations in online news publications. Journalism, 19(11), 1497-1516. https://doi.org/10.1177/ 1464884916683549

Lee, C. C., He, Z., \& Huang, Y. (2007). Party-market corporatism, clientelism, and media in Shanghai. Harvard International Journal of Press/Politics, 12(3), 21-42. https://doi.org/10.1177/1081180X07303216

Lee, T. V., \& Li, C. C. (2000). Power, money, and media: Communication patterns and bureaucratic control in cultural China. Northwestern University Press.

Lim, M. (2012). Clicks, cabs, and coffee houses: Social media and oppositional movements in Egypt, 2004-2011. Journal of Communication, 62(2), 231-248. https://doi.org/10.1111/j.1460-2466. 2012.01628.x

Linstrom, M., \& Marais, W. (2012). Qualitative news frame analysis: A methodology. Communitas, 17(1), 21-38.

Liu, H., Wu, T., \& Xu, Y. (2020). The dynamics of China's attitude towards implementing the responsibility to protect in the Middle East and North Africa. Mediterranean Politics, 25(1), 1-28. https://doi.org/ 10.1080/13629395.2020.1769317

Lynch, D. C. (1999). After the propaganda state. Stanford University Press.

Lynch, M. (2011). After Egypt: The limits and promise of online challenges to the authoritarian Arab state. Perspectives on Politics, 9(2), 301-310. https://doi.org/ 10.1017/S1537592711000910

Lynch, M. (2013). The Arab uprising: The unfinished revolutions of the new Middle East. Hachette.

Meidan, M. (2006). China's Africa policy: Business now, politics later. Asian Perspective, 30(4), 69-93.

Natarajan, K., \& Hao, X. (2003). An Asian voice? A comparative study of Channel News Asia and CNN. Journal of Communication, 53(2), 300-314. https://doi.org/ 10.1111/j.1460-2466.2003.tb02592.x

Pan, Z., \& Chan, J. M. (2003). Shifting journalistic paradigms: How China's journalists assess "media exemplars." Communication Research, 30(6), 649-682. https://doi.org/10.1177/0093650203257 843

Pan, Z., \& Lu, Y. (2003). Localizing professionalism: Discursive practices in China's media reform. In C. C. Lee (Ed.), Chinese media, global contexts (pp. 215-236). Routledge; Curzon; Taylor \& Francis Group.

Papacharissi, Z. (2016). Affective publics and structures of storytelling: Sentiment, events and mediality.
Information, Communication \& Society, 19(3), 307-324. https://doi.org/10.1080/1369118X.2015. 1109697

Qin, Y. (2018). A relational theory of world politics. Cambridge University Press.

Qiu, J. L. (1999). Virtual censorship in China: Keeping the gate between the cyberspaces. International Journal of Communications Law and Policy, 4(1), 25.

Reah, D. (2002). The language of newspapers. Psychology Press.

Robertson, A. (2015). What's going on? Making sense of the role of the media in the Arab uprisings. Sociology Compass, 9(7), 531-541. https://doi.org/ $10.1111 /$ soc 4.12278

Rodny-Gumede, Y. (2020). Expanding comparative media systems analysis from transitional to postcolonial societies. International Communication Gazette, 82(7), 611-627. https://doi.org/10.1177/ 1748048519897515

Shambaugh, D. (2017). China's propaganda system: Institutions, processes and efficacy. In K. E. Brodsgaard (Ed.), Critical readings on the Communist Party of China (pp. 713-751). Brill. https://doi.org/10.1163/ 9789004302488_026

Shen, S. (2004). Nationalism or nationalist foreign policy? Contemporary Chinese nationalism and its role in shaping Chinese foreign policy in response to the Belgrade embassy bombing. Politics, 24(2), 122-130. https://doi.org/10.1111/j.1467-9256.2004.00213.x

Shichor, Y. (2013). Fundamentally unacceptable yet occasionally unavoidable: China's options on external interference in the Middle East. China Report, 49(1), 25-41. https://doi.org/10.1177/0009445513479219

Shirk, S. L. (2007). Changing media, changing foreign policy in China. Japanese Journal of Political Science, 8(1), 43-70. https://doi.org/10.1017/S146810990 7002472

Shoemaker, P. J., \& Reese, S. D. (2013). Mediating the message in the 21st century: A media sociology perspective. Routledge.

Singh, M. (2016). Chinese policy in the Middle East in the wake of the Arab uprisings. Palgrave Macmillan.

Smith, J., \& Fetner, T. (2009). Structural approaches in the sociology of social movements. In B. Klandermans \& C. Roggeband (Eds.), Handbook of social movements across disciplines (pp. 13-57). Springer.

Stockmann, D., \& Gallagher, M. E. (2011). Remote control: How the media sustain authoritarian rule in China. Comparative Political Studies, 44(4), 436-467. https://doi.org/10.1177/0010414010394773

Sun, D., \& Zoubir, Y. (2018). China's participation in conflict resolution in the Middle East and North Africa: A case of quasi-mediation diplomacy? Journal of Contemporary China, 27(110), 224-243. https://doi.org/ 10.1080/10670564.2018.1389019

Tianyancha. (2021). Caixin media. https://www. tianyancha.com/brand/b206a112032

Tuchman, G. (1978). Making news: A study in the con- 
struction of reality. Free Press.

Tzogopoulos, G. N. (2014). The beginning of the "Arab Springs": A provisional analysis of coverage in Western and Chinese media. L'Europe en formation, 1(371), 128-134.

Van Dijk, T. A. (1993). Principles of critical discourse analysis. Discourse \& Society, 4(2), 249-283. https://doi. org/10.1177/0957926593004002006

Wang, H. (2003). National image building and Chinese foreign policy. China: An International Journal, 1(1), 46-72. https://doi.org/10.1142/S0219747203 000050

Wang, J., \& Wang, X. (2014). Media and Chinese foreign policy. Journal of Contemporary China, 23(86), 216-235. https://doi.org/10.1080/10670564.2013. 832523

Weaver, D. A., Lively, E., \& Bimber, B. (2009). Searching for a frame: News media tell the story of technological progress, risk, and regulation. Science Communication, 31(2), 139-166. https://doi.org/10.1177/ 1075547009340345

Wu, M. (2006). Framing AIDS in China: A comparative analysis of US and Chinese wire news coverage of HIV/AIDS in China. Asian Journal of Communication, 16(3), 251-272.

Yin, J. (2007). The narrative function of news: A comparative study of media representation and audience interpretation of China-US trade relationship. China Media Research, 3(3), 33-42.

Yu, X. (2011, August 3). Aiji qianzongtong mubalake shouci tingshen kaishi [The first trial of former Egyptian President Mubarak began]. Caixin Net. https://international.caixin.com/2011-08-03/ 100287208.html

Zhang, J. (2015). China's new foreign policy under Xi Jinping: Towards "peaceful rise 2.0"? Global Change, Peace \& Security, 27(1), 5-19. https://doi.org/ 10.1080/14781158.2015.993958

Zhang, S. I. (2012). The newsroom of the future: Newsroom convergence models in China. Journalism Practice, 6(5/6), 776-787. https://doi.org/10.1080/ 17512786.2012.667281

Zhao, S. (2013). Foreign policy implications of Chinese nationalism revisited: The strident turn. Journal of Contemporary China, 22(82), 535-553. https://doi. org/10.1080/10670564.2013.766379

Zhao, Y. (2009). Rethinking Chinese media studies: History, political economy and culture. In D. K. Thussu (Ed.), Internationalizing media studies (pp. 189-209). Routledge.

Zhong, S. (2011, August 29). Xunzhao shihe benguo guoqing de fazhan daolu [Looking for a development path suited to China's national conditions]. People's Daily. http://data.people.com.cn/rmrb/pd.html

\section{About the Authors}

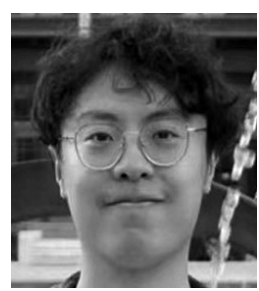

Shiming $\mathrm{Hu}$ is a doctoral candidate at the School of Journalism and Communication, Beijing Normal University. His research interests include media effect, internet communication, and internet governance. He is researching how barrage influences users' viewing experiences and opinions in the streaming media environment. In addition, he focuses on two things: how games as a medium affects social relations, and the dynamic mechanism for players who watch live games.

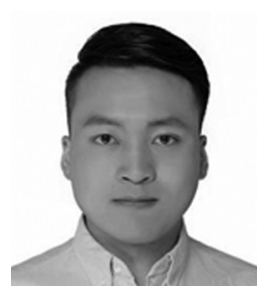

Weipeng Hou is a doctoral candidate at the School of Journalism and Communication, Beijing Normal University. His research interests are internet communication and internet governance.

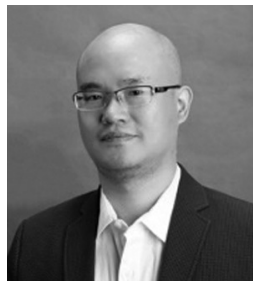

Jinghong $\mathbf{X u}$ is a professor at the School of Journalism and Communication, Beijing Normal University. His research interests include new media and internet governance, health communication, intercultural communication, film and television study, and game research. 